\title{
Coseismic slip in the mantle: evidence from the 1989 Macquarie Ridge earthquake
}

\author{
Helen Anderson $\left({ }^{1}\right)$ and Jiajun Zhang $\left({ }^{2}\right)$ \\ (') Kelburn Centre, DSIR Geology and Geophysics, Wellington, New Zealand \\ $\left.{ }^{2}\right)$ Institute of Tectonics, University of California, Santa Cruz, U.S.A.
}

\begin{abstract}
The rupture process of the $M_{\mathrm{S}} 8.2,23$ May, 1989 Macquarie Ridge earthquake was studied using a surface wave inversion procedure that incorporates detailed source-time functions obtained from shorter-period body waves. The seismic-source model obtained using this method is consistent with observations of both body waves and of $28 \mathrm{~s}$ and a right-lateral This mechanism is consistent the long-period Rayleigh waves (periods from 150 ions of the event. Allowing for uncertainty in attenuation, a seismic moment of between 1.7 and $2.1 \times 10^{21} \mathrm{Nm}$ and $\mathrm{s}$ ) indicate that the Macquarie Ridge earthquake had $\mathrm{km}$. The centroid depth range, combined that significant slip occurred beneath the M lack of resolvable directivity of the earthquake rupture, suggests region. We infer that the mantle slip co Moho, which has a maximum depth of about $16 \mathrm{~km}$ in the epicentral shorter-period body wave observations indicate preferentially radiated long-period seismic energy because the determined from the surface wave inversion.

Similar studies of other great earthquakes in oceanic crust (e.g., 1977 Sumba and 1977 Tonga) indicate that these was required to explain the surface in the upper part of the plate but that significantly deeper moment release of the lithosphere, although the slip distributions some great earthquakes appear to rupture a significant thickness the plate. Recognition of this phenomenon has is probably modified by the different rheological properties of
\end{abstract}

\section{Introduction}

The depth distribution of earthquakes shows concentrations in the upper crust and upper mantle (Chen and Molnar, 1983). This is usually correlated with strength profiles and interpreted as two separate regions of the lithosphere that fail independently. Major earthquakes, with large fault areas, might have their slip confined to the upper crust (for instance) but have significantly long faults lengths or large coseismic slip to accommodate the moment release. The earthquakes that rupture the upper and middle crust with significant fault length caused broad surface deformation and seismic wave radiation directivity and they can be recognized with geological and seismological observations. Alternatively brittle failure associated with large earthquakes may not be confined to the brittle layer of the crust or mantle, and whole lithosphere rupture might occur. We have tested these alternatives by examining the rupture process of the largest earthquake since 1977, the 23 May 1989 Macquarie Ridge earthquake.

The 1989 Macquarie Ridge earthquake occurred in an isolated area about $800 \mathrm{~km} \mathrm{SSW}$ of New Zealand (fig. 1). The earthquake is significant in its tectonic setting, focal mechanism, large size $\left(M_{\mathrm{S}}=8.2\right)$ and rupture process. It was the largest event located along the Pacific-Australian plate boundary south of New Zealand in more than 70 years. The fault slip of the Mac- 


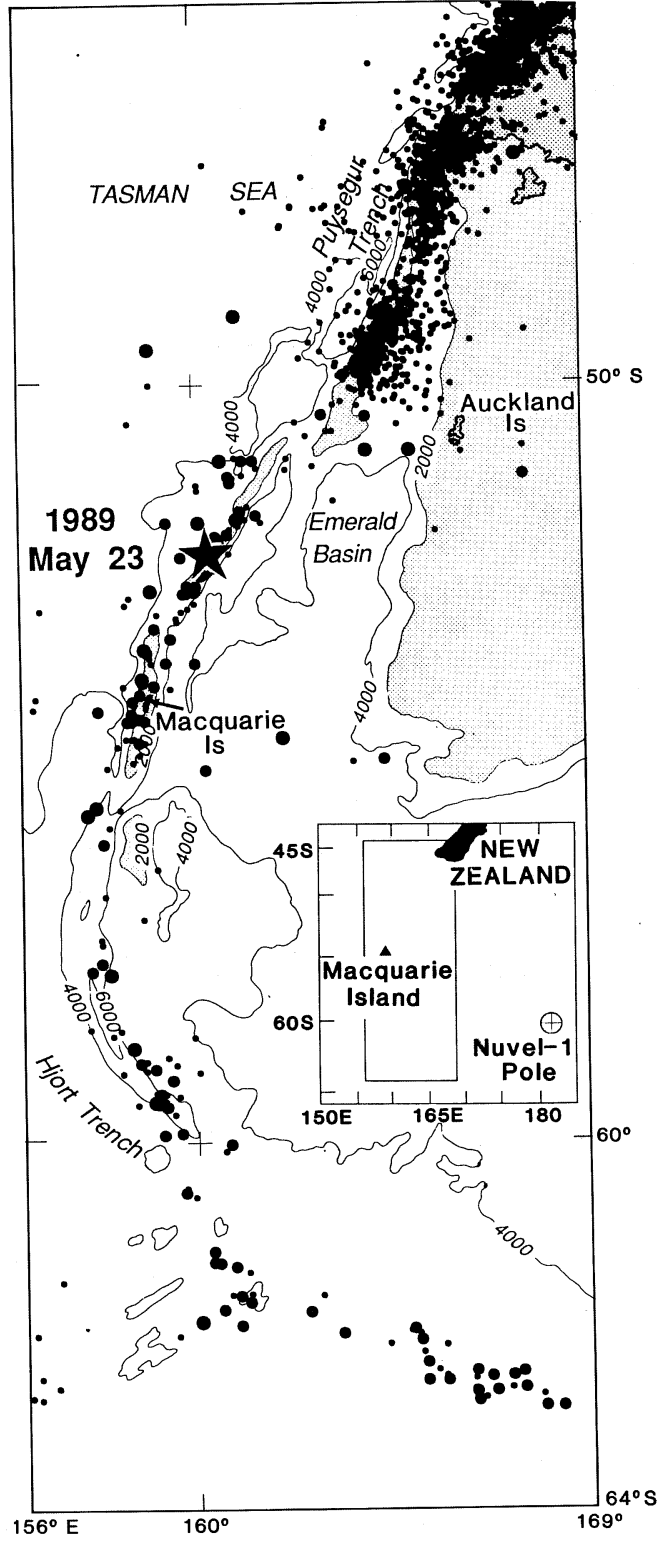

Fig. 1. Seismicity distribution along the Macquarie Ridge Complex with shaded area indicating bathymetry less than $2000 \mathrm{~m}$. All earthquakes shown are for 1918 to 24 May 1989 from the historical catalogue of the International Seismological Centre. Various symbols indicate epicentral locations of events of the 23 May 1989 (star), magnitude less than 5.0 (small dots), and magnitude 6.0 or larger (large dots). quarie Ridge earthquake therefore represents a large amount of seismic deformation occurring on this plate boundary, and contributes significantly to the relative motion between the Australian and Pacific plates.

The Macquarie Ridge earthquake has been analyzed using seismic body waves (Braunmiller and Nabelek, 1990; Dziewonski and Zwart, 1989; Ekström and Romanowicz, 1990; Houston, 1990; Satake and Kanamori, 1990; Tichelaar and Ruff, 1990) and long-period surface waves and free oscillations (Dziewonski and Zwart, 1989; Ekström and Romanowicz, 1990; Kedar and Tanimoto, 1990; Park, 1990; Satake and Kanamori, 1990). These studies show that it was a large shallow strike-slip event, with a relatively short source process time compared to other earthquakes of similar size. However, due to the difficulties in modelling seismic body and surface wave excitations for the earthquake, estimates of the source parameters of the Macquaire Ridge earthquake are subject to large uncertainties. Table I lists some important source parameters of this earthquake obtained by various investigators.

The ranges of total process time (sometimes termed duration in other studies) obtained from both body waves and surface waves are large (table I), and there appears to be a systematic increase in the seismic moment and depth with the period of seismic waves used in the inversion. An explanation for the greater depth determined from surface waves, compared to body waves, is not immediately obvious, but the variation in moment and process time can be explained if significant moment release occurs at longer periods than those used in an inversion, in which case the total moment and process time will be underestimated. Similarly, surface wave inversion methods lack resolution at the relatively short periods required to define a detailed moment rate function.

In order to obtain a unified source process model for the Macquaire Ridge earthquake that is compatible with both the body and surface wave data, we used a method described by Anderson and Zhang (1991), which incorporates the detailed moment rate function (pre-determined from body waves) in the surface wave inversion. We compare our results with those from other 
methods and discuss the physical significance and tectonic implications of the source process for the Macquaire Ridge earthquake.

\section{Tectonic setting and crustal structure}

The Macquaire Ridge earthquake occurred in a region of complicated tectonics (fig. 1). The Macquaire Ridge Complex is defined by a belt of seismicity, which follows elongate ridges and trenches from the southwest corner of the South Island, New Zealand to the Australian-AntarcticPacific triple junction (van de Linden and Hayes, 1972; Summerhayes, 1967a,b) forming several distinct segments of the plate boundary (Anderson, 1990). Rocks on Macquaire Island have been derived from oceanic crust that was uplifted to the present elevation within the last $10 \mathrm{Ma}$ (Williamson, 1988), suggesting that the elongate ridges along the Macquaire Ridge Complex are probably the result of obduction processes.

While the complexity of bathymetry and the presence of obducted oceanic crust suggest a tectonic regime influenced by compression, seismic slip on the central portion of the Macquaire Ridge Complex is predominantly strike-slip. The $P$-wave first- motion mechanism for the Macquaire Ridge earthquake is essentially vertical strike-slip (fig. 2) with a strike $\left(038^{\circ}\right)$ almost

Table I. Source parameters for the 1989 Macquarie Ridge earthquake.

\begin{tabular}{|c|c|c|c|c|c|c|c|}
\hline Author(s) & $\begin{array}{l}\text { Inversion } \\
\text { type }\end{array}$ & $\begin{array}{c}\text { Moment } \\
\left(\times 10^{21} \mathrm{Nm}\right)\end{array}$ & $\begin{array}{l}\text { Depth } \\
(\mathrm{km})\end{array}$ & $\begin{array}{c}\text { Source } \\
\text { process } \\
\text { time }(\mathrm{s})^{\mathrm{a}}\end{array}$ & $\begin{array}{l}\text { Distinct } \\
\text { sub- } \\
\text { events }\end{array}$ & $\begin{array}{l}\text { Directivity } \\
\text { resolvable? }\end{array}$ & $\begin{array}{c}\text { Mechanism } \\
\text { strike/dip/ } \\
\text { rake }\end{array}$ \\
\hline \multirow{2}{*}{$\begin{array}{l}\text { Ekström and } \\
\text { Romanowicz } \\
\text { (1990) }\end{array}$} & $\begin{array}{l}\text { Rayleigh } \\
160 \mathrm{~s}<T<320 \mathrm{~s}\end{array}$ & $\begin{array}{l}2.4 \\
1.8\end{array}$ & $\begin{array}{l}50 \\
20^{\mathrm{b}}\end{array}$ & $\begin{array}{l}(28) \\
(28)\end{array}$ & - & - & $\begin{array}{l}040 / 82 / 181 \\
040 / 69 / 186\end{array}$ \\
\hline & $\begin{array}{l}\text { Broadband } \\
P+S H\end{array}$ & 1.8 & 15 & $\begin{array}{l}(28) \\
75\end{array}$ & $\begin{array}{l}- \\
-\end{array}$ & $\begin{array}{c}- \\
\text { No }\end{array}$ & $\begin{array}{l}040 / 69 / 186 \\
029 / 90 / 178\end{array}$ \\
\hline \multirow{2}{*}{$\begin{array}{l}\text { Satake and } \\
\text { Kanamori } \\
(1990)\end{array}$} & $\begin{array}{l}\text { Rayleigh } \\
\text { and Love }\end{array}$ & 1.8 & $10^{\mathrm{b}}$ & $(30)$ & - & - & $131 / 65 / 13$ \\
\hline & $\begin{array}{l}\text { Broadband } \\
P+S H\end{array}$ & 1.1 & $10^{\mathrm{b}}$ & 30 & 4 & Yes & $228 / 87 / 18^{c}$ \\
\hline $\begin{array}{l}\text { Tichelaar } \\
\text { and Ruff } \\
(1990)\end{array}$ & $P+S H$ & 1.8 & 12 & 20 & No & No & $212 / 85 / 185$ \\
\hline $\begin{array}{l}\text { Braumiller } \\
\text { and Nabelek } \\
(1990)\end{array}$ & $P+S H$ & $\begin{array}{l}1.34 \\
0.47^{d} \\
0.55\end{array}$ & $\begin{array}{l}10 \\
10^{\mathrm{b}}\end{array}$ & $\begin{array}{l}52 \\
16 \\
30\end{array}$ & $\begin{array}{l}4 \\
2\end{array}$ & Yes & $\begin{array}{l}211 / 86 / 180 \\
210 / 95 / 174 \\
212 / 82 / 187\end{array}$ \\
\hline $\begin{array}{l}\text { Dziewonski } \\
\text { and Zwart } \\
(1989)\end{array}$ & $P($ and $S H ?)$ & 1.4 & 10.5 & 32 & 2 & No & \\
\hline $\begin{array}{l}\text { Kedar and } \\
\text { Tanimoto } \\
(1990)\end{array}$ & $\begin{array}{l}\text { Normal mode } \\
(962 \mathrm{~s})\end{array}$ & $2.8 \pm 0.5$ & & - & - & - & $\begin{array}{c}\text { used Satake } \\
\text { and } \\
\text { Kanamori } \\
(1990)\end{array}$ \\
\hline This study & $\begin{array}{l}\text { Rayleigh } \\
150 \mathrm{~s}<T<300 \mathrm{~s}\end{array}$ & $\begin{array}{l}2.11^{\mathrm{e}} \\
1.75^{\mathrm{f}}\end{array}$ & $\begin{array}{l}28 \\
15\end{array}$ & $\begin{array}{l}93(28) \\
92(28)\end{array}$ & - & $\begin{array}{l}\text { azimuth } \\
\text { only }\end{array}$ & $\begin{array}{l}038 / 86 / 180 \\
037 / 75 / 178 \\
\end{array}$ \\
\hline \multicolumn{8}{|c|}{$\begin{array}{l}\text { a No. in brackets indicates centroid time } \approx 1 / 2 \text { process time. } \\
\text { b Fixed. } \\
\text { c Largest sub-event }\end{array}$} \\
\hline
\end{tabular}




\section{Macquarie Ridge}

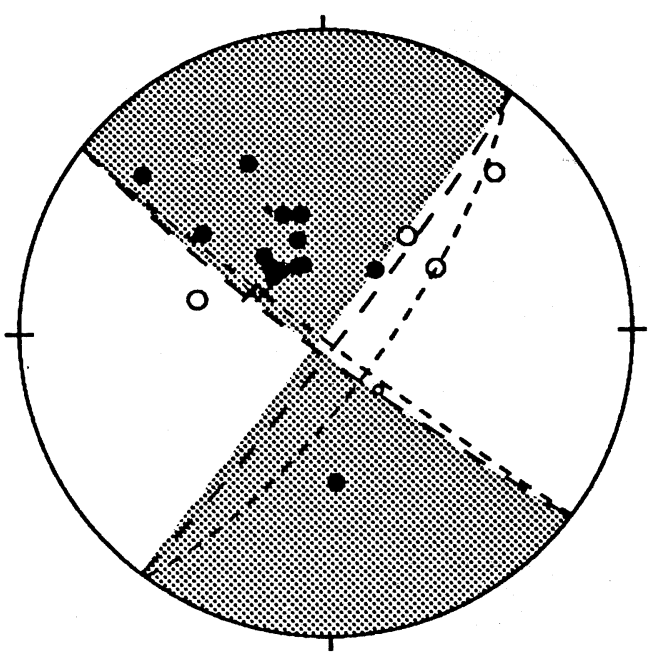

\section{May 23}

Fig. 2. Focal mechanism (lower hemisphere equal-area projection) determined from $P$-wave firstmotion polarities on long-period vertical WWSSN records with compressional quadrants shaded. Open circles indicate dilatations and dots indicate compressions. Nodal planes of the best double couple of the moment tensor solution obtained in this study using default earth models (long-dashed lines) and using the Masters and Gilbert (1983) Q model for attenuation and Regan and Anderson (1984) 20 to 50 Ma ocean model for excitations (short-dashed lines) are also shown.

parallel to the relative plate motion direction for the epicentral area $\left(041^{\circ}\right)$ predicted using the DeMets et al. (1990) pole position.

Knowledge of the crustal structure in the epicentral area is important for both body and surface wave inversions for earthquake source parameters. Detailed velocity structure for the epicentral area is not known, but gravity and bathymetry data suggest that the Moho depth in the epicentral region is between 12 and $16 \mathrm{~km}$ (Williamson, 1988). For body wave analysis, the resolution of source characteristics is limited by the extreme variations in water depth (250 to $5250 \mathrm{~m}$ within $50 \mathrm{~km}$ of the epicenter), which produce complex $P$-wave water multiples
(Weins, 1989). However, for our surface wave analysis, the crustal structure on a broader scale (within several hundred kilometers of the epicenter) affects the estimates of source parameters, in particular the depth.

\section{Method}

We used long-period Rayleigh wave spectra from the Macquarie Ridge earthquake that had been calculated at periods of $150,175,200,225$, 256, 275 and $300 \mathrm{~s}$ using data from the Global Seismograph Network (GSN) and GEOSCOPE (Romanowicz et al., 1984) networks.

For the surface wave inversion (which is described in detail by Anderson and Zhang, 1991), we used a two-step inversion developed by Zhang and Kanamori (1988a). The first step isolates the source-finiteness effect, and the second step finds the best depth and moment tensor.

Body wave studies for the Macquarie Ridge earthquake indicate that the high-frequency source process consists of several sub-events with most of the moment released in the first subevent spanning about $24 \mathrm{~s}$ long (e.g., Braunmiller and Nabelek, 1990; Ekström and Romanowicz, 1990; Tichelaar and Ruff, 1990). The source time function (represented by a series of isosceles triangles) obtained by Braunmiller and Nabelek (1990), using the most complete data set was included in our surface wave inversion and the longer-period component was represented by a half-sine. We used only the first $24 \mathrm{~s}$ of the moment rare function determined by Braunmiller and Nabelek because the later pulses probably reflect unmodelled water reverberations in the $P$ waveforms (Weins, 1989).

In our inversions we used default models for the earth structure to calculate phase velocity, attenuation and excitation functions. In order to test whether any sistematic bias in the source parameters is introduced by the choice of this Earth model we repeated all our calculations with several different Earth models.

\section{Results}

The surface wave inversion results obtained 
using a simple body wave moment rate function are shown in fig. 3. If the shape of the early part of the source time function described by isosceles triangles is fixed, three parameters are required to define our combined moment rate model. The first is the process time, $\tau$, of the half-sine; the second is the ratio of the half-sine component to the total moment rate function, $\gamma(0 \leq \gamma \leq 1)$; and the third is the total moment. For $\gamma=0$ only the body wave moment rate function, defined by the isosceles triangles, contributes to the total-moment rate function. A $\gamma$ value of about 0.45 minimizes errors and maximizes the contribution of the body wave moment rate function. In this case the total moment is about $2.11 \times 10^{21} \mathrm{Nm}$, with a corresponding optimal process time of $93 \mathrm{~s}$ and centroid depth of $28 \mathrm{~km}$.

For the above calculations we used an average ocean excitation model (Regan and Anderson, 1984) and an attenuation model determined by Dziewonski and Steim (1982). We performed calculations with other values of young ocean (Regan and Anderson, 1984) and an attenuation model determined by Masters and Gilbert (1983). This latter combination produces an indistinguishable moment rate function but the values for some of the source parameters differed significantly. The centroid depth determined was $15 \mathrm{~km}$
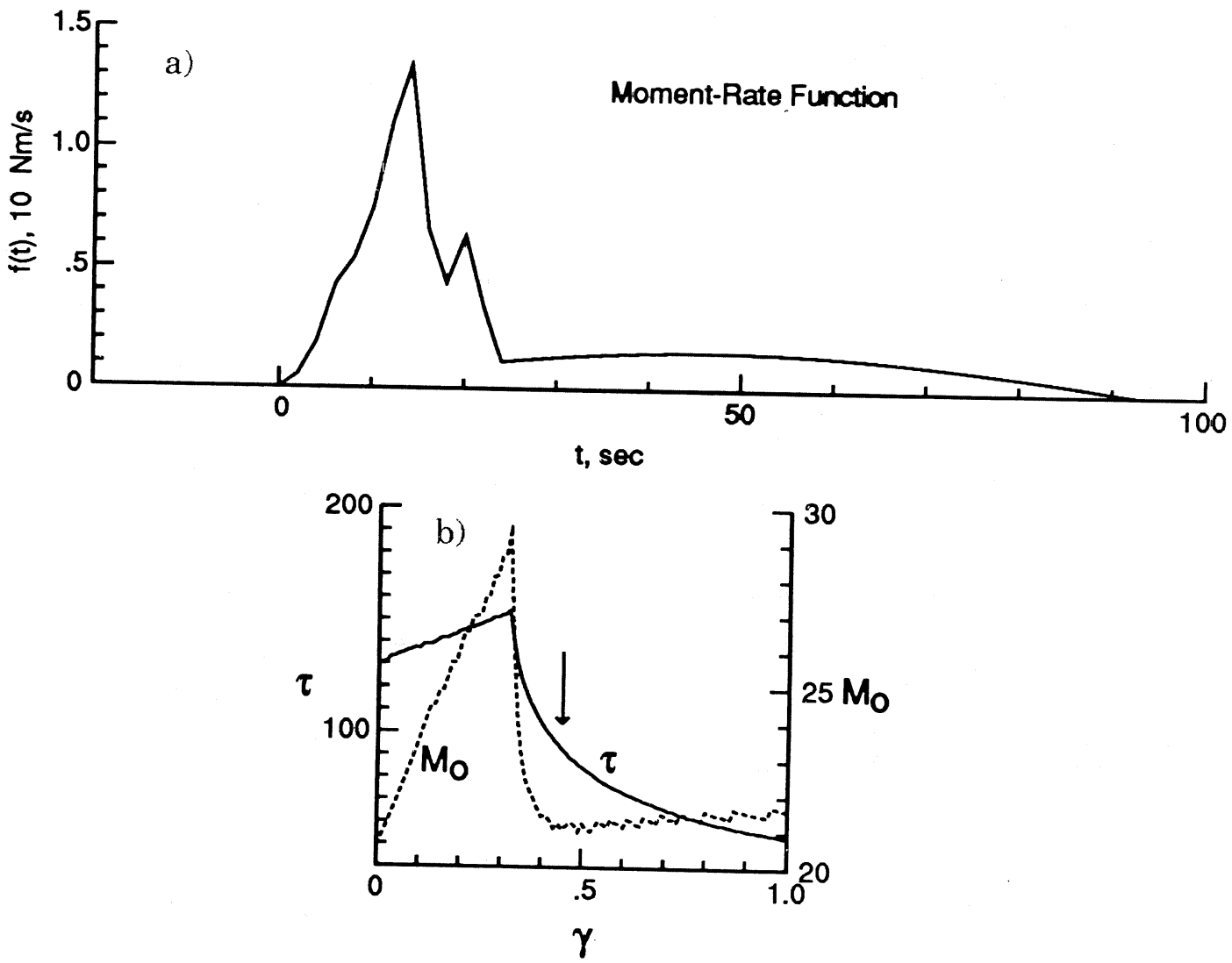

Fig. 3. a) The moment rate functions for the Macquarie Ridge earthquake. The first $24 \mathrm{~s}$ of the moment rate function for a point source determined by Braunmiller and Nabelek (1990) using body waves is combined with a half-sine representing the long-period component. b) The process time $\tau$ (solid line) and total moment (dashed line) plotted against $\gamma$. The arrow indicates the chosen value of $\gamma(0.45)$ that maximizes the contribution of the body waves to the total moment and minimizes the errors (see Anderson and Zhang, 1991 for more details). 
and the total moment was $1.74 \times 10^{21} \mathrm{Nm}$. We are not aware of any a priori reason to prefer either of the attenuation models (which had the most significant effect on the depth and total moment), so source parameter values for both are presented in table I.

\section{Discussion}

\subsection{Process time}

From inversions of the long-period Rayleigh waves, the rupture process of the Macquarie Ridge earthquake had a centroid time of about $28 \mathrm{~s}$ and lasted $93 \mathrm{~s}$. This indicates that the greatest moment release of the event occurred in the early part of the rupture. The difference in the moments determined using body waves, surface waves and free ocillations require a delayed centroid time (about $28 \mathrm{~s}$ ) from the 10 to $15 \mathrm{~s}$ body wave centroid time.

The Macquarie Ridge earthquake was unusual in being a relatively simple event for its size. The moment rate functions of most other large earthquakes obtained from body wave observations usually consist of two or more distinct episodes of concentrated moment release each with a process time of $20 \mathrm{~s}$ or a few seconds longer (e.g., 1977 Tonga, Zhang and Lay, 1989a,b; 1979 Colombia, Beck and Ruff, 1984, Kanamori, 1986; 1986 Andreanof Is., Houston and Engdahl, 1989).

However, most of the large earthquakes available for similar surface wave studies have been thrust or normal faulting events. A detailed study of other large strike-slip earthquakes in a similar tectonic setting would be necessary to establish whether source simplicity is a characteristic of such events.

\subsection{Focal mechanism}

The best double-couple focal mechanism determined from our surface wave inversion using the default earth models is very similar to that determined from first motions (fig. 2). This suggests that the earthquake rupture was simple, and that there were no major sub-events with a focal mechanism significantly different from the first-motion solution.

The northeast striking nodal plane is roughly parallel to the regional trend of the bathymetry $\left((35 \pm 5)^{\circ}\right)$ and the predicted plane motion direction (41 ${ }^{\circ}$, NUVEL-1 pole, DeMets et al., 1990) so it probably represents the fault plane. The aftershock locations determined by the National Earthquake Information Center (NEIC) are spread out over a large area (fig. 4) and have depths fixed at $10 \mathrm{~km}$ so they do not clearly define a fault plane. Relocation of the aftershock could refine this pattern slightly, but only 8 events had $M_{\mathrm{S}}$ greater than 5.0 and none exceeded 6.0 , so the number of well-recorded events suitable for relocation is small.

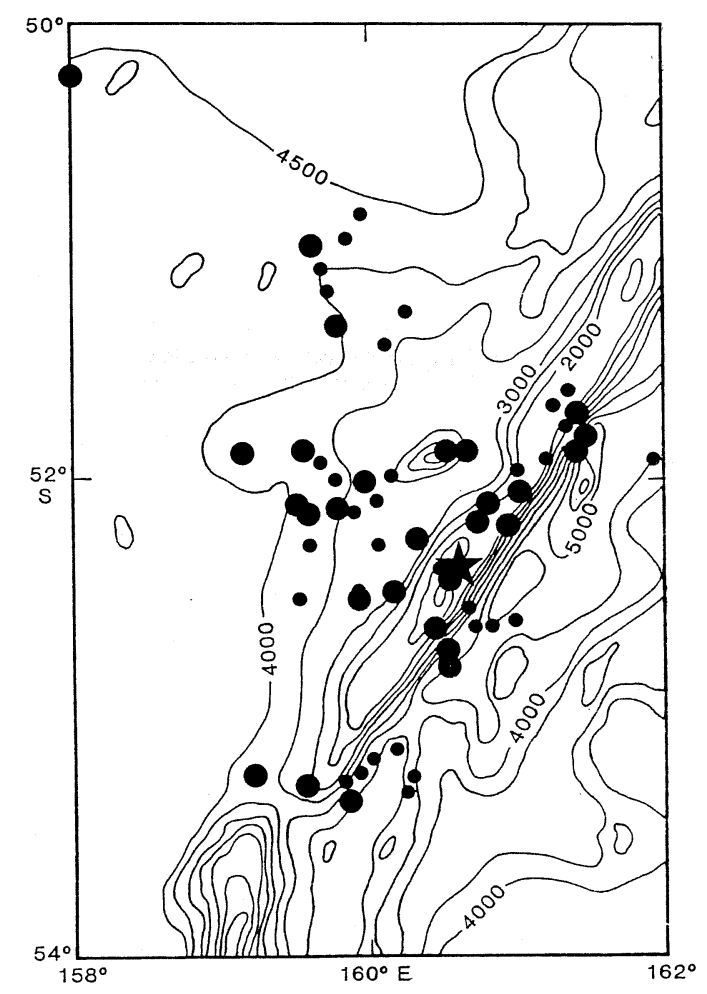

Fig. 4. Aftershocks of the 23 May 1989 Macquarie Ridge earthquake located by the International Seismological Centre for the period from 23 May 1989 to 17 September 1990 . The largest dots are events greater than 5.0 and no aftershock exceeded $m_{b}$ 5.9. The mainshock location is shown by a star. 


\subsection{Depth extent of faulting}

The centroid depth obtained using surface waves ranges from 15 to $28 \mathrm{~km}$, depending on the model used for earth structure. This range includes other values determined from both body waves and surface waves with simple moment rate functions (table I), although the body wave centroid depths tend to be much shallower than our range. This may suggest that surface waves are sensitive to slip at deeper levels than can be resolved using body waves.

The Moho depth beneath the epicentral area varies from about 12 to $16 \mathrm{~km}$ (Williamson, 1988). Our range of possible centroid depths indicates that al least some seismic slip occurred in the upper mantle during the Macquarie Ridge earthquake. If uniform slip occurred, then the base of the rupture extent could range from 30 to $56 \mathrm{~km}$, although uniform slip seems unlikely because of the marked change in physical properties at the Moho. The preliminary determination of hypocentral depth (10 km, NEIC) does not indicate that this was an unusually deep event so it probably initiated at a relatively shallow depth, either within the crust or upper mantle, with slip occurring in both.

Significant rheological differences would exist from the top to the bottom of any fault that ruptures through the crust and into the mantle. Hartzell and Heaton (1988) suggest that under these conditions, the lower section of the fault may not radiate as much high-frequency energy as the upper brittle section. The mantle slip component may therefore have preferentially radiated long-period energy thus producing the apparent discrepancies between the body wave and surface wave durations, moments and centroid depths.

The conditions under which the mantle fails brittly is related to several parameters, such as composition, temperature, pressure and strain rate. Experimental studies have shown that the depth at which the transition from brittle to ductile behaviour occurs in the mantle increases with increasing strain rate (Ashby and Verrall, 1977). At the high strain rates experienced during such a large earthquake, the upper mantle is probably able to deform brittly, while at subcrustal depths smaller aftershocks would not occur. The NEIC aftershocks of the Macquarie Ridge earthquake are spread over a broad region, and this also supports our interpretation of significant subcrustal deformation, since if slip were concentrated in a narrow zone in the crust, post-earthquake strain redistribution as manifest by aftershocks should be similarly concentrated.

It is known that earthquakes may occur in the upper mantle beneath oceanic crust (Chen and Molnar, 1983) but the Macquarie Ridge earthquake is unusual in probably having seismic slip in both the crust and mantle. Other large normal faulting earthquakes are thought to have ruptured significant thicknesses of the lithosphere (1977 Sumba and 1977 Tonga, Lay et al., 1988; 1933 Sanriuku, Kanamori, 1971), and since all of these events have occurred in regions with oceanic crust, it would probably require an even larger earthquake $\left(M_{\mathrm{W}} \sim 8.2\right)$ to rupture relatively thicker but weaker continental crust. Major faults in the upper mantle have been recognized in deep seismic profiles in continental regions (e.g., Flannan Fault, Matthews and Cheadle, 1986, Flack et al., 1990). These faults dip at a low angle and are thought to have been normal or thrust faults so they are inappropriate for direct comparison with the Macquarie Ridge tectonic setting but, nevertheless, they suggest that brittle failure has occurred in the mantle. Our model for the rupture process of the Macquarie Ridge earthquake indicates seismic slip on a fault that breaks through both the crust and uppermost mantle.

The effects of rupture directivity of the Macquarie Ridge earthquake are small. Although our results show a preferred azimuth similar to the strike of the northeast striking nodal plane, the actual direction of the rupture propagation cannot be resolved. This is an unexpected result for such a large earthquake. Other earthquakes of similar moment often have well-resolved directivity effects (e.g., 1979 Colombia, Zhang and Kanamori, 1988b) but these are shallow events with dominantly horizontal rupture extent in continental areas. The small directivity effects are probably the result of the downward continuation of slip, which is favoured in this case by the steep dip of the fault in an oceanic crust.

The suggestion that some large earthquakes may involve whole lithosphere failure has important implications. Coseismic failure of the mantle requires either high frictional strength of 
the uppermost mantle or at least sufficient strain accumulation that high strain rate loading can drive brittle fracture. Whatever the mechanism by which coseismic failure occurs in the mantle, it means that direct scaling of ground motion and other hazard-related parameters to large-scale strike slip earthquakes should be made with extreme caution. The recognized failure of selfsimilarity for other large earthquakes is also probably related to brittle failure in regions of significantly different rheology (Hartzell and Heaton, 1988).

\section{Conclusions and implications}

Source process parameters determined for the Macquarie Ridge earthquake by various authors show a significant difference in values obtained from body and surface waves (table I). We have presented a modification of a two-step surface wave inversion method that incorporates a detailed body wave moment rate function and so allows us to determine a unified model for the source process.

Using our unified model we determine ranges for various source parameters. The estimates of process and centroid times are about 93 and $28 \mathrm{~s}$, respectively. This indicates that the moment release was concentrated in the early part of the rupture, and long-period moment release continued for at least $93 \mathrm{~s}$. The best double-couple focal mechanism is well resolved and is very similar to that derived from first motions. The ranges of values of moment $((1.75 \div 2.11) \times$ $10^{21} \mathrm{Nm}$ ) and centroid depth (15 to $\left.28 \mathrm{~km}\right)$ derived using different earth models are large.

The depth range and lack of significant directivity suggest that at least some slip occurred in the mantle during this earthquake. The rupture may have initiated in either the crust or upper mantle but slip probably occurred through the entire lithosphere.

\section{REFERENCES}

ANDERSON, H.J. (1990): The 1989 Macquarie Ridge earthquake and its contribution to the regional seismic moment budget, Geophys. Res. Lett., 17, 1013-1016.
ANDERSON, H. and J. ZHANG (1991): Long-period seismic radiation from the May 23, 1989, Macquarie Ridge earthquake: evidence for coseismic slip in the mantle?, $J$. Geophys. Res., 96, 19 853-19 863.

ASHBY, M.F. and R.A. VERRALL (1977): Micromechanism of flow and fracture, and their relevance to the rheology of the upper mantle, Philos. Trans. R. Soc. London, Ser. A, 288, 59-95.

BECK, S.L. and L.J. RuFF (1984): The rupture process of the great 1979 Colombia earthquake: evidence for the asperity model, J. Geophys. Res., 89, 9281-9291.

BRAUNMILLER, J. and J. NABELEK (1990): Rupture process of the Macquarie Ridge earthquake of May 23, 1989, Geophys. Res. Lett., 17, 1017-1020.

CHEN, W.P. and P. MOLNAR (1983): Focal depths of intracontinental and intraplate earthquakes and their implications for the thermal and mechanical properties of the lithosphere, J. Geophys. Res., 88, 4183-4214.

De MEts, C., R.G. Gordon, D.F. Argus and S. Stein (1990): Current plate motions, Geophys. J. Int., 101, 425-478.

Dziewonski, A. M. and J.M. STEIM (1982): Dispersion and attenuation of mantle waves through waveform inversion, Geophys. J. R. Astron. Soc., 70, 503-527.

DzIEWONSKI, A.M. and G. ZWART (1989): The Macquarie Ridge earthquake of 23 May 1989, EOS Transactions A.G.U., 70, 1196.

Ekström, G. and B. RomanowiCZ (1990): The 23 May 1989 Macquarie Ridge earthquake: a very broad band analysis, Geophys. Res. Lett., 17, 993-996.

FlaK, C.A., S.L. KLEMPERER, S.E. MCGEARY, D.B. SyNDER and M.R. WARNER (1990): Reflections from mantle fault zones around the British Isles, Geology, 18, 528-532.

HARTZELL, S.H. and T.H. HEATON (1988): Failure of selfsimilarity for large $\left(M_{\mathrm{w}}>8.25\right)$ earthquakes, Bull. Seismol. Soc. Am., 78, 478-488.

Houston, H. (1990): Broad band source spectrum, seismic energy and stress drop of the 1989 Macquarie Ridge earthquake, Geophys. Res. Lett., 17, 1021-1024.

Houston, H. and E.R. ENGDAHL (1989): A comparison of the spatiotemporal distribution of moment release for the 1986 Andreanof Islands earthquakes with relocated seismicity, Geophys. Res. Lett., 16, 1421-1424.

KANAMORI, H. (1971): Seismological evidence for a lithospheric normal faulting - the Sanriuku earthquake of 1993, Phys. Earth Planet. Int., 4, 289-300.

KANAMORI, H. (1986): Rupture process of subduction-zone earthquakes, Ann. Rev. Earth Planet. Sci., 14, 293-322.

Kedar, S. and T. TAnimoto (1990): Moment of the Macquarie Island earthquake from free oscillation data, EOS Transactions A.G.U., 71, 558.

LAY, T., C. LyNNES and D. CHRISTENSEN (1988): Great intraplate normal-faulting earthquakes: do they rupture the entire lithosphere?, Seismol. Res. Lett., 59, 7.

MAsters, G. and F. GILBERT (1983): Attenuation in the earth at low frequency, Philos. Trans. R. Soc. London, Ser. A, 308, 479-522.

MATTHEWs, D.H. and M.J. CheADLE (1986): Deep reflections from the Caledonides and Variscides west of Britain and comparison with the Himalayas, in Reflection Seismology: A global perspective, edited by M. BARAZANGI and L. Brown, American Geophysical Union Geodynamics Series, 13, pp. 55-66. 
PARK, J. (1990): Radial mode observation from the 5/23/89 Macquaire Ridge earthquake, Geophys. Res. Lett., 17, 1005-1008.

Regan, J. and D.L. Anderson (1984): Anisotropic models of the upper mantle, Phys. Earth Planet. Int., 35, 227-263.

Romanowicz, B., M. CARA, J.F. Fels and D. Rouland (1984): GEOSCOPE: A French initiative in long-period three-component global seismic networks, EOS Transactions A.G.U., 65, 753-756.

SATAKE, K. and H. KANAMORI (1990): Fault parameters and tsunami excitation of the May 23, 1989, Macquarie Ridge earthquake, Geophys. Res. Lett., 17, 997-1000.

SuMmerHAYES, C.P. (1967a): Macquarie Bathymetry, New Zealand Oceanographic Institute Chart, Oceanic Series, 1:1,000,000.

SummerhAYES, C.P. (1967b): Auckland Bathymetry, New Zealand Oceanographic Institute Chart, Oceanic Series, 1:1,000,000.

TICHELAAR, B.W. and L.J. RUFF (1990): Rupture process and stress drop of the great Macquaire Ridge earthquake, Geophys. Res. Lett., 17, 1001-1004.
VAN DER LINDEN, W.J.M. and D.E. HAYES (1972): Resolution Bathymetry, New Zealand Oceanographic Institute Chart, Oceanic Series, 1:1,000,000.

WEINS, D.A. (1989): Bathymetric effects on body waveforms from shallow subduction zone earthquakes and applications to seismic process in the Kurile Trench, J. Geophys. Res., 94, 2955-2972.

Williamson, P.E. (1988): Origin, structural and tectonic history of the Macquarie Island region, R. Soc. Tasmania, Papers and Proceedings, 122, 27-43.

ZHANG, J. and H. ZANAMORI (1988a): Depths of large earthquakes determined from long-period Rayleigh waves, $J$. Geophys. Res., 93, 4850-4868.

ZHANG, J. and H. KANAMORI (1988b): Source finiteness of large earthquakes measured from long-period Rayleigh waves, Phys. Earth Planet. Int., 52, 56-84.

ZHANG, J. and T. LAY (1989a): A new method for determining the long-period component of the source time function of large earthquakes, Geophys. Res. Lett., 16, 175-278.

ZHANG, J. and T. LAY (1989b): Source duration and depth extent of the June 22, 1977 Tonga earthquake, Bull. Seismol. Soc. Am., 79, 51-66. 